\title{
Adverse drug reactions to ibuprofen: a case report
}

\author{
Khobragade Yadneshwar*, Khobragade Sujata
}

\begin{abstract}
Department of Community Medicine, Melaka-Manipal Medical College, Melaka, Malaysia
\end{abstract}

Received: 03 November 2015

Revised: 05 November 2015

Accepted: 18 December 2015

\section{*Correspondence to:}

Dr. Yadneshwar Khobragade, Email: drkhobragade@yahoo.com

Copyright: (C) the author(s), publisher and licensee Medip Academy. This is an open-access article distributed under the terms of the Creative Commons Attribution Non-Commercial License, which permits unrestricted non-commercial use, distribution, and reproduction in any medium, provided the original work is properly cited.

\begin{abstract}
Ibuprofen is a commonly used drug available by prescription and over the counter for treatment of fever, joint pain, headache, migraine, inflammatory states. It is available in combination with paracetamol and various other drugs. Side effects associated with aspirin \& non-steroidal anti-inflammatory drugs (NSAIDs) are rash, gastrointestinal ulcers, hepatic toxicity, Steven Johnson syndrome, respiratory skin rashes, acute exacerbation of asthma and anaphylaxis. We have reported here severe distress hypersensitive reaction with ibuprofen induced hypersensitivity syndrome. Within two hours of consumption of ibuprofen patient developed severe bronchospasm, throat \& laryngeal oedema leading to respiratory distress. He was treated with salbutamol, hydrocortisone, deriphylline and supportive oxygen, but did not respond and went into coma. Unlike acetaminophen, ibuprofen does not have any antidote hence managing adverse drug reactions (ADR) due to ibuprofen is big challenge. Therefore understanding pathophysiology of ADR to Ibuprofen is necessary to manage the patient. Literature in the field of allergic drug reaction shows that epinephrine, a physiological antagonist of histamine is the first drug of choice for the treatment of allergic or drug induced angioedema, laryngeal oedema and bronchospasm due to its direct action on target organs. Such reactions should therefore be managed by epinephrine without loss of time. ADR due to ibuprofen could be prevented by (a) avoiding unnecessary intake of drug, (b) educating patients / families and public about adverse drug reactions (c) surveillance and monitoring of drug reactions (d) record keeping (e) drug audit and (f) reporting of ADR to state/central pharmacovigilance agency. We do observe doctors having misconception about adrenaline, its actions, usage \& side effects especially cardio-vascular, hence are reluctant to use. But in severe violent adverse drug reaction we have to use our wisdom and judgement and see whether usage of adrenaline overweighs the ADR or not. In acute drug reaction like this where respiratory system is compromised use adrenaline could have been helpful. We therefore suggest adequate teaching of the field of adverse drug reactions, early diagnosis of drug reactions and judicious use of epinephrine if warranted.
\end{abstract}

Keywords: Ibuprofen, Cystaennyl leukotriene, Histamine, Adverse drug reactions, Cerebral hypoxia, Angioedema, Bronchospasm, Anaphylaxis, Anaphylactoid

\section{INTRODUCTION}

Adverse drug reaction (ADR) is a major public health problem. Due to increased dissemination of information via internet, television and other electronic media, usage of drugs has increased. Over the counter purchase of medicine is widespread all over the world. In developing countries, ibuprofen either alone or in combination with paracetamol is widely used. Idiosyncrasy, over dosage, prolonged usage does cause adverse effects. Paracetamol, diclofenac, aspirin, ibuprofen, indomethacin, naproxen and rofecoxib have been associated with ADR. The prevalence varies from $18-78 \%$ depending on NSAIDs used (Table 1). Most common ADR seen in children with these antipyretic, analgesic drugs are skin rashes (47.5\%), anaphylaxis $(10.6 \%)$ and less common are Steven Johnson syndrome, generalized exanthemata, toxic epidermal necrolysis, hepatic, gastrointestinal and respiratory. In adults, ADR to ibuprofen are approximately twenty six percent and reactions range from skin reactions to acute bronchospasm, acute exacerbation of asthma, angioedema and anaphylaxis (Table 2). ${ }^{1-3}$ 
Table 1: Types of class students found helpful $(\mathrm{N}=230)$.

\begin{tabular}{|c|c|c|c|c|}
\hline Author & Total cases with ADR & ADR due to NSAIDs & Percentage & Study age group \\
\hline Thirza et al ${ }^{1}$ & 754 & 19 & $2.5 \%$ & Children \\
\hline Gor, Saksena $^{3}$ & 100 & 26 & $26 \%$ & 18-65 years \\
\hline Kromann-Anderson, Pederson ${ }^{4}$ & 3521 & 2721 & $78 \%$ & 17 years follow up \\
\hline Hiware et al ${ }^{12}$ & 2693 & 486 & $18 \%$ & $21-40$ years \\
\hline Shi et al $^{16}$ & 1002 & 504 & $50 \%$ & Elderly \\
\hline Kidon MI, See $\mathrm{Y}^{17}$ & 222 & 42 & $18.5 \%$ & Children \\
\hline
\end{tabular}

Table 2: Aspirin / NSAIDs and No. of patients reported with ADR.

\begin{tabular}{|c|c|c|c|c|c|c|}
\hline Authors & Skin rashes & $\begin{array}{l}\text { Gastro- } \\
\text { intestinal }\end{array}$ & $\begin{array}{l}\text { (a)Respiratory } \\
\text { (b) Acute } \\
\text { exacerbation of } \\
\text { asthma }\end{array}$ & $\begin{array}{l}\text { Cardio- } \\
\text { vascular } \\
\text { /anaphylaxis }\end{array}$ & $\begin{array}{l}\text { (a)Angioedema } \\
\text { (b) Steven } \\
\text { Johnson } \\
\text { syndrome }\end{array}$ & Death \\
\hline Thirza et al ${ }^{1}$ & 10 & 5 & 4 & - & - & 1 \\
\hline Joanna $^{11}$ & - & - & $\begin{array}{l}\text { (a) } 81 \\
\text { (b) } 06\end{array}$ & - & - & - \\
\hline Shi $W$ et al ${ }^{16}$ & 90 & 572 & - & - & - & _- \\
\hline $\begin{array}{l}\text { Lapeyre-Mestre } \\
\text { M et al }{ }^{18}\end{array}$ & $\begin{array}{l}\text { Most frequent } \\
\text { occurrence Of } \\
\text { severe ADR }\end{array}$ & $2^{\text {nd }}$ highest & - & $\begin{array}{l}\text { Rare } \\
\text { occurrence }\end{array}$ & - & - \\
\hline $\begin{array}{l}\text { Huic M et al }{ }^{19} \\
\text { Aspirin } \\
\text { NSAIDs }\end{array}$ & $\begin{array}{l}38.5 \% \\
23.1 \%\end{array}$ & - & - & - & - & - \\
\hline $\begin{array}{l}\text { JAUHARI AC } \\
\text { et al } \text { al }^{20}\end{array}$ & 1 & - & - & - & - & $\begin{array}{l}1 \text { death due } \\
\text { to } \\
\text { thrombocyto } \\
\text { penia }\end{array}$ \\
\hline $\begin{array}{l}\text { Leśniak M et } \\
\mathrm{al}^{21}\end{array}$ & - & - & - & $31 \%$ & 1 (b) & - \\
\hline $\begin{array}{l}\text { Sánchez-Borges } \\
M \text { et al }{ }^{22}\end{array}$ & - & - & - & - & $0.1-0.3 \%$ (a) & - \\
\hline
\end{tabular}

The acute exacerbation of asthma is brought about by aspirin and non-steroidal anti-inflammatory drugs through cyclooxygenase 1 inhibition. The reduction in level of prostaglandin $\mathrm{E}_{2}$ activates inflammatory response leading to increased release of cysteinyl-leukotrienes systemically and locally in respiratory passage. Cysteinyl leukotrienes are 3-4 times potent than histamine in causing contraction of airway smooth muscles, increased secretion of bronchial mucus and increased vascular permeability leading to bronchoconstriction and angioedema. $^{5-7,15}$ Involvement of respiratory system may be life threatening, hence immediate detection of severity of ADR and its management is essential.

Epinephrine has both alpha and beta receptor activity. It directly acts on the receptors of effector organs, thus causing relaxation of smooth muscles of bronchial tree, contraction of smooth muscle fibres of cardiovascular system. Innervation of sympathetic nerve fibres is not necessary for its action on the contrary denervation increases the sensitivity of effector organs. ${ }^{8}$ Unlike antihistamines which are competitive inhibitors, epinephrine prevents release of additional chemicals such as leukotrienes, histamine, bradykinin etc. ${ }^{9}$

Patient had minor injury over his finger followed by infection with pus formation.

Incision and drainage was done and was prescribed ibuprofen. Within 2 hours after taking this medicine patient developed severe violent allergic reaction leading to laryngeal oedema, bronchospasm, swelling of lip, throat and eye ball. He had respiratory distress, for which he was given bronchodilators, steroids and antihistamines but got no relief. He developed cerebral hypoxia and went into coma while on the way to tertiary hospital. He is still in semiconscious state. Present case is a known case of bronchial asthma; he had taken ibuprofen few months before but did not get any adverse effect.

Our objective of discussing this case is:

1. To present clinical manifestations of ADR to ibuprofen and the consequences it can lead to. 
2. Understand the pathophysiology of this severe drug reaction and its management.

3. Prevention of such adverse drug reaction.

4. Health education.

\section{CASE HISTORY}

Patient 34 years old presents with the complaint of pain in little finger due to injury.

\section{Present history}

Patient had minor injury over his finger followed by infection with pus formation (paronychia). Incision and drainage was done in OPD at primary level hospital in Mumbai on $18^{\text {th }}$ August 2006. As the finger was very painful treating physician advised him ibuprofen.

Within two hours of taking ibuprofen he developed following symptoms \& signs:

1. Severe breathing difficulty

2. Inability to talk, unable to lie down on bed

3. Chocking sensation in throat

4. Suffused eyes

Patient presented with -

1. High respiratory rate with laboured breathing and signs of air hunger

2. High pulse and blood pressure

3. Confuse and drowsy

4. Wheezing

Patient was a known case of bronchial asthma getting attacks intermittently depending on the season.

The treating physician reported that he inquired about any allergic drug reaction in the past. Patient denied of having any major drug reaction and he informed the doctor that in the event of any reaction he will report back to him.

However, on taking Ibuprofen later, the patient suffered with severe ADR. On arrival at the hospital, the Patient was given pheniramine maleate intramuscularly and put on nebulizer with salbutamol, ipratropium bromide and budesonide but he did not get relief.

So he was given Injectable

1. Deriphyllin

2. Hydrocortisone

But condition did not improve, the patient developed cyanosis; respiratory rate reduced to around 4-6/minutes and had altered level of consciousness. He was immediately transferred to super speciality hospital with nurse attendant. On the way patient lost consciousness, his pulse \& blood pressure dropped.
In the referral hospital patient was shifted to ICU, diagnosed as ADR to ibuprofen leading to acute exacerbation of bronchial asthma, glottal and laryngeal oedema and angioedema. The patient underwent tracheotomy and was put on respirator. All other revival measures were taken. After 7 days on respirator patient was stabilized and respirator was put off, though patient survived he could not gain consciousness. MRI scan of brain showed changes consistent with hypoxia. Ever since this adverse drug reaction, the patient suffered from unresponsive wakefulness syndrome and had been provided very good care with support from referral centers. In February 2007, some improvement had been seen such as making eye contact; smiling and weeping when tried to communicate. Currently patient is on supportive treatment and physiotherapy to prevent muscle wasting of limbs.

\section{Past history}

Few months before this event patient had taken ibuprofen with no major side effect. However his mother said that her son had slight discomfort and had been advised not to take ibuprofen.

\section{Personal history}

Patient is highly qualified man, is non-smoker, noalcoholic but has history of asthma. He claimed to never have had any severe drug reaction in the past and was not allergic to paracetamol. Since he is unable to communicate, we are unable to get history related to any side-effect he had with Ibuprofen on initial consumption.

\section{Family history}

He is married, currently looked after by mother, father and sister. Nobody in family has bronchial asthma.

\section{DISCUSSION}

Ibuprofen is a phenyl propionic acid derivative, used as antipyretic and analgesic drug. It is inferior as antiinflammatory. ${ }^{8}$ It can be used as single or in combination. When used with acetaminophen, antipyretic and analgesic effects are pronounced. Side effects are dose related. In higher doses and usage for prolonged period, it may cause gastric irritation, peptic ulcer and hematemesis. ${ }^{10}$ Aspirin sensitive asthmatic patient may get hypersensitivity to NSAIDs with oral medication, parenteral or even eye drops with normal doses hence it is contraindicated in patients having nasal polyps, angioedema and bronchial asthma. ${ }^{11}$ Atopic patients are more prone to get ADR to ibuprofen. The concerned patient developed angioedema $\&$ acute bronchospasm to ibuprofen. Initial intake of ibuprofen did not cause obvious reaction but subsequent use lead to severe reaction, it may be due to earlier sensitization. 
Studies show, NSAIDs cause mild skin allergy, bronchospasm, angioedema, anaphylaxis, toxic epidermal necrolysis. ${ }^{1,7,12}$ This patient developed allergic bronchial asthma \& angioedema after taking one tablet of ibuprofen. He presented with swelling over lip, orbital area, throat and severe breathing difficulty. He was unable to sit and talk. He was given Avil \& was put on nebulizer with salbutamol, ipratropium bromide and steroids but could not breathe in, therefore given parenterally hydrocortisone, deriphyllin \& pheniramine maleate however; patient's condition deteriorated further and started losing consciousness therefore transferred to higher level hospital. His MRI scan report is consistent with cerebral hypoxia. At tertiary level hospital he was tracheotomised, put on respirator and necessary treatment was given. Though patient survived but for last 8 years he is in semi-coma with slight improvement. History given by parents suggests that patient is not allergic to paracetamol. This is confirmed because he is still in hospital and whenever he gets fever doctors prescribe acetaminophen. The adverse drug reaction he had is due to ibuprofen. Ibuprofen inhibits cyclooxygenase (COX) enzymes leading to increased synthesis of cysteinyl leukotrienes, prostaglandins and thromboxane causing glottal \& laryngeal oedema, increased bronchial secretion, and contraction of non-vascular smooth muscle fibres and dilatation of vascular smooth muscle fibres. The bronchi and bronchioles are clogged with mucus. ${ }^{7,13}$ This is anaphylactoid reaction, if not treated promptly, can endanger life. For anaphylaxis/anaphylactoid the treatment of choice is adrenaline and not anti-histamines, steroids \& beta-agonists. Because anti-histamines act as competitive antagonists \& blocks the action of histamine but does not reverse the changes that have already occurred. Also it does not prevent further release of histamine from mast cells. Moreover time taken for action is long. It takes more than 30 minutes to act whereas patient in anaphylaxis can die in 5 minutes, (2) the steroids act as anti-inflammatory and reduces inflammatory process, it acts indirectly by (a) potentiating alfa 1 adrenergic action on bronchial arterial smooth muscles (b) suppression of genetic transcription of cytokines, and (c) time taken for action is 4-24 hours, (3) bronchodilators no longer work because bronchioles are already stretched by presence of thick mucoid secretions. $8,9,14$

\section{CONCLUSION}

Review of literature and recent studies suggest that epinephrine relieves angioedema with anaphylactoid reaction caused by ibuprofen because of its direct action on bronchial smooth muscles, bronchial mucosa and vasculature. Therefore epinephrine is first line drug in ADR involving respiratory system, angioedema, cardiovascular system. Anti-histamines, steroids and betaagonist can be used as adjuvant. We feel that trial of epinephrine in this patient may have been more beneficial as it would have reversed the effects of histamine and leukotriene released in ADR due to Ibuprofen. In order to prevent ADR we recommend:

1. Surveillance, monitoring and education of patients are important in preventing adverse drug reactions.

2. ADR should be recorded in file and communicated to patients. Manufacture of combination of two or more drugs should be banned.

3. There should be proper audit of prescriptions and notification of ADR should be made mandatory.

4. Patients should be educated on prevention of selfmedication.

Inputs from clinical pharmacologists, physicians or neurologists are most welcomed for improved management which can help in faster recovery of the patient.

\section{Funding: No funding sources}

Conflict of interest: None declared

Ethical approval: The study was approved by the Institutional Ethics Committee

\section{REFERENCES}

1. Titchen T, Cranswick N, Beggs S. Adverse drug reactions to nonsteroidal anti-inflammatory drugs, COX-2 inhibitors and paracetamol in a paediatric hospital. Br J Clin Pharmacol. 2005;59(6):718-23.

2. Nanau RM, Neuman MG. Ibuprofen-induced hypersensitivity syndrome. Translational Research. 2010;155(6):275-93.

3. Gor AP, Saksena M. Adverse drug reactions of nonsteroidal anti-inflammatory drugs in orthopedic patients. J Pharmacol Pharmacother. 2011;2(1):26-9.

4. Kromann-Andersen H, Pedersen A. Reported adverse reactions to and consumption of nonsteroidal anti-inflammatory drugs in Denmark over a 17-year period. Dan Med Bull. 1988;35(2):187-92.

5. Kowalski ML, Makowska JS, Blanca M, Bavbek S, Bochenek G, Bousquet J, et al. Hypersensitivity to nonsteroidal anti-inflammatory drugs (NSAIDs) classification, diagnosis and management: review of the EAACI/ENDA and GA2LEN/HANN. Allergy. 2011;66(7):818-29.

6. Berger A. What are leukotrienes and how do they work in asthma? BMJ 1999;319. doi: http://dx.doi.org/10.1136/bmj.319.7202.90.

7. Kaplan AP. Angioedema. World Allergy Organ J. 2008;1(6):103-13.

8. Mayers FH, Jawetz E, Goldfien A. Review of medical pharmacology. $7^{\text {th }}$ edition. Lange medical publications, California, Los Altos;1980:43,187.

9. Wood JP, Traub SJ, Lipinski C. Safety of epinephrine for anaphylaxis in the emergency setting. World J Emerg Med. 2013;4(4):245-51. 
10. Moore N, Pollack C, Butkerait P. Adverse drug reactions and drug-drug interactions with over-thecounter NSAIDs. Ther Clin Risk Management. 2015;11:1061-75.

11. Sturtevant J. NSAID-induced bronchospasm: A common and serious problem. Prescriber Update. 1999;18:22-4.

12. Hiware S, Shrivastav M, Mishra D, Mukhi J, Puppalwar G. Evaluation of cutaneous drug reactions in patients visiting outpatient departments of Indira Gandhi Medical college and Hospital, Nagpur. Indian J Dermatol. 2013;58(1):18-21.

13. Sánchez-Borges M, Caballero-Fonseca F, CaprilesHulett A, González-Aveledo L. Hypersensitivity reactions to nonsteroidal anti-inflammatory drugs: An Update Pharmaceuticals. 2010;3:10-8.

14. Alagiri AA. Genomic and non-genomic actions of glucocorticoids in asthma. Ann Thorac Med. 2010;5(3):133-9.

15. Busse WW. Leukotrienes and Inflammation. Am J Respir Crit Care Med. 1998;157(6):S210-3.

16. Shi W, Wang Y, Li S,Yan M, Li D, Chen B, Cheng N. Risk factors of adverse drug reaction from nonsteroidal anti-inflammatory drugs in Shanghai patients with arthropathy. Acta Pharmacol Sin. 2004;25(3):357-65.
17. Kidon MI, See Y. Adverse drug reactions in Singaporean children. Singapore Med J. 2004;45(12):574-7.

18. Lapeyre-Mestre M, Grolleau S, Montastruc J, Association Française des Centres Régionaux de Pharmacovigilance (CRPV). Adverse drug reactions associated with the use of NSAIDs: a case/non-case analysis of spontaneous reports from the French pharmacovigilance database 2002-2006. Fundam clin pharmacol. 2013;27(2):223-30.

19. Huic M, Mucolic V, Vrhovac B, Francetic I, Bacran I, Giljanovics S. Adverse drug reactions resulting in admissions Int $\mathbf{J}$ clin Pharmacol Th. 1994;32(12):675-82.

20. Jauhari AC, Bista D, Johorey AC, Saha S, Saha A. Thrombocytopenia after ibuprofen. J clinical diag res. A case report. 2009;3(1):1329-33.

21. Leśniak $M$, Woron $J$, Czarnobilska E. Lifethreatening drug reactions in children. Przegl Lek. 2013;70(12):1003-7.

22. Sánchez-Borges M, Capriles-Hulett A, CaballeroFonseca F. NSAID-induced urticaria and angioedema: a reappraisal of its clinical management. Am J Clin Dermatol. 2002;3(9):599607.

Cite this article as: Khobragade Y, Khobragade S. Adverse drug reactions to ibuprofen- a case Report. Int J Basic Clin Pharmacol 2016;5:215-9. 